\title{
Investing in Hedge Funds: A Survey
}

\author{
Keith H. Black, CFA \\ Ennis Knupp + Associates
}

\begin{abstract}
Although the media and many investors perceive hedge funds to be uniformly risky, the facts are that little about the hedge fund universe is homogenous. Some hedge funds hedge, whereas others take directional market risks. As a result of the private and opaque nature of hedge fund investing, a multitude of data challenges exist because hedge funds are not required to report their returns to regulators or any single database. Much of the literature describes adjustments and caveats to working with as-reported hedge fund returns and risk data.
\end{abstract}

"Hedge fund" is a term used to describe a wide variety of investment strategies. As a general rule, these strategies are less regulated and more opaque than long-only funds offered by traditional investment managers. Rather than taking a long-only exposure to a single asset class, many hedge fund strategies involve the use of leverage, derivative products, multiple asset classes, and short selling. The net market exposure of hedge funds can vary over time, which makes it more difficult to analyze performance, manage risk, and decide on the proper allocation of hedge funds in investor portfolios.

Stulz (2007) draws several contrasts between mutual funds and hedge funds. Hedge fund assets have grown explosively to more than $\$ 1$ trillion, which is now more than 10 percent of the size of the mutual fund industry.

In the United States, mutual funds are required to report to the U.S. Securities and Exchange Commission (SEC). This requirement includes filing a prospectus, full disclosure of portfolio holdings on a semiannual basis, and the daily dissemination of a net asset value (NAV). Mutual funds are also subject to limits on leverage. In exchange for this regulation, mutual fund providers are allowed to market their products to a wide variety of investors, ask for low minimum investments, and offer universal availability to investors.

Hedge funds may earn exemptions from many of these regulatory requirements. By choosing to not market their investments to the public and restricting fund investments to certain types of high-net-worth investors, hedge funds are exempt from disclosure requirements. The unregulated nature of hedge funds, then, simply refers to the ability to provide less disclosure to investors and little or no disclosure to noninvestors. The opaque nature of hedge funds makes it difficult to calculate exact statistics on the size and performance of hedge funds because even their existence may not be disclosed.

Although exempt from disclosure requirements, hedge funds are not entirely unregulated. Hedge fund managers must still follow other laws determined by securities regulators. Hedge funds may not misrepresent performance, steal client funds, or engage in insider trading, manipulative trading, or front running.

In contrast to the low minimum investment and daily liquidity of mutual fund shares, investments in hedge funds are much less liquid. Most hedge funds report a NAV at the end of each month or calendar quarter. Many hedge funds also have lockup periods that restrict withdrawals from the hedge fund for some period of time. Popular lockups at hedge funds are one and two years, and three-year lockups are becoming more common. A "hard lockup" states that no provisions exist for the redemption of hedge fund investments for the stated period of time. A "soft lockup" period suggests a minimum investment period, but investors have the ability to sell their shares before the expiration of the lockup period by paying a redemption fee, which is often in the range of 1-3 percent. As a result of regulatory requirements that limit the number of investors in each fund, hedge funds typically have high minimum investment requirements, generally ranging from $\$ 500,000$ to $\$ 10$ million per investor. 


\section{Fee Structures}

Much has been written about hedge fund fee structures. Hedge fund performance is typically reported net of all fees. Stulz (2007) explains that hedge funds can earn both management fees and incentive fees. A typical management fee is 1-2 percent annually based on the assets under management. Incentive fees, also called performance fees, are calculated as a set percentage of the profits on the underlying pool of assets. A hedge fund manager might earn 15-25 percent of profits in addition to the management fee. Few mutual funds charge performance fees because U.S. regulations require the fees to be symmetrical, meaning the investment manager must share equally in both gains and losses.

Hedge fund incentive fees are paid on a quarterly or annual basis and are often subject to a high-water mark provision. These fees are earned by a manager only during time periods of positive investment performance. The high-water mark provision ensures that incentive fees are earned only once for a given dollar of investment return. For example, a hedge fund earns a 10 percent gain, net of fees, in a calendar year for which incentive fees are paid. If the fund posts a return of -9 percent the following year, no incentive fees are paid because performance was negative. In the next year, the hedge fund returns 15 percent. The incentive fees in that year are paid only on the gains in excess of the high-water mark, which is the 5 percent of gains in excess of the NAV of the fund at the end of the first year. Anson (2001) has described hedge fund incentive fees as a free call option because the manager earns high fees for large investment gains but does not share in any investor losses. This lack of sharing in losses could provide an incentive for the manager to take risks larger than the investor would choose. An offsetting factor to this asymmetrical fee structure is when the investment manager has invested a substantial portion of his or her net worth in the fund, which would cause the manager and the investor to simultaneously experience trading losses.

Although a large percentage of hedge funds use a high-water mark in their fee calculations, a small minority also use hurdle rates. Hedge funds with hurdle rates do not earn any incentive fee until a minimum return threshold has been reached. Typical hurdle rates may be a stated short-term interest rate or a fixed annual rate, such as 5 percent.

Some investors have chosen not to allocate assets to hedge funds because of the size of fees paid to hedge fund managers. Asness (2006) suggests several modifications to hedge fund fee structures. Higher hedge fund fees should be paid to managers that have demonstrated skill by earning alpha, which is a high return after adjusting for all applicable risks. Leveraged hedge funds may also justify higher fees because these strategies earn a greater benefit from the manager's insight for each dollar of invested capital. Hedge fund investors are starting to separate alpha from beta in their performance calculation, leading them to ask hedge funds to charge lower fees for beta exposures to traditional market factors. By replacing high beta hedge funds with index funds or hedge fund beta replications (see the section "Hedge Fund Replication"), investors can substantially reduce the fees they pay. As the hedge fund industry comes to rely more on institutional investors, such as pension plans, and less on highnet-worth individuals, hedge fund fees for larger investments are likely to decline.

\section{A Wide Variety of Hedge Fund Strategies}

Black (2004) provides a comprehensive overview of hedge fund strategies and follows the fund style classification methodology of the Credit Suisse/Tremont Hedge Fund Index (www.hedgeindex.com).

Arbitrage-based funds typically have a lower standard deviation of returns because they are the hedge funds that explicitly hedge. By design, the risk and size of the long positions are highly correlated with the risk and size of the short positions. In many cases, these funds have short volatility exposures that lead to gains in quiet markets and losses in turbulent markets. These strategies typically have annualized standard deviations of 5-7 percent, which result in the highest Sharpe ratios of all hedge fund strategies. Many of these strategies, however, make money slowly and lose money quickly, which leads to unattractive negative skewness and fat tail risk (i.e., large excess kurtosis).

Convertible bond arbitrage strategies purchase a portfolio of convertible bonds and take short positions in the related equity security. A convertible bond is typically a corporate debt issue that includes a call option on the stock price of the issuer. Investors accept a lower yield on convertible bonds compared with option-free debt of the same issuer because they are compensated for the lower yield through the call option. For example, a 
corporation that typically borrows at 7 percent in the bond market may issue a convertible bond with a 4 percent yield, which prices the call option at the present value of the foregone 3 percent interest. A convertible bond strategy is deemed to be market neutral when the price of the fund does not change with small changes in the underlying stock prices. Market neutrality is achieved when the size of the short-stock position matches the longdelta position of the embedded call options. Convertible bond arbitrage performs well in times of declining credit spreads and high stock price volatility. In times of rising credit spreads, convertible bond arbitrage funds can suffer steep losses because bond prices are falling quickly and liquidity of convertible bonds declines rapidly in a flight to quality market.

Equity market neutral funds seek to take, on average, a zero beta exposure to equity markets. Many funds aim for a zero exposure on average but may take temporary risks of up to a beta of \pm 0.20 . Although beta risks are minimized in this strategy, fund managers may take substantial risks in other areas of the equity markets, such as market capitalization, value, growth, or industry. To reach beta neutrality, the size and beta of the long positions are closely matched through the size and beta of the short positions. Many market neutral funds are driven through a quantitative process. Quantitative funds with longer holding periods (months) may be based on factor models with such themes as value, growth, momentum, and earnings quality. Quantitative funds with shorter holding periods (minutes to days) may be called statistical arbitrage and are largely based on trading long-short pairs of stocks with a high long-term correlation with divergent short-term stock movements.

Event driven funds are focused on a single strategy, such as distressed investments or risk arbitrage. Multistrategy implementations of event driven investing can combine these two strategies with others, such as spinoffs, cross-ownership, or index reconstitution strategies. Distressed funds typically invest in debt securities of issuers currently in default or expected to default soon. Distressed funds have, perhaps, the most significant liquidity risk of any hedge fund strategy because many investors are not willing or able to buy the debt of firms currently in bankruptcy. Distressed investors can be passive, simply willing to earn the return on the bonds they purchase. Others, however, are very active investors who will become involved in the bankruptcy process. Capital structure arbitrage implementations of distressed investments include spreads between many parts of a given company's capital structure, perhaps by buying debt and selling short the stock or trading credit default swaps against stock options.

Risk arbitrage, or merger arbitrage, funds seek to predict the outcome of announced corporate merger transactions. The classic implementation is to purchase the stock of the target company and sell short the stock of the acquiring company in the ratio of the stock swap transaction. This strategy is the definition of event risk and higher moment risk because these funds make money slowly and lose money quickly. The target return of a successful investment may be only 5-10 percent, which is earned during the 3-18 months between the announcement and consummation of the deal. Risk arbitrage funds can experience substantial losses when a planned merger is cancelled because the stock of the target company can fall 30 percent or more in a single day. Risk arbitrage is considered a short volatility strategy because the hedge fund has sold insurance against a broken deal in consideration of the expected return of the completed deal.

Fixed-income arbitrage typically invests with a positive income orientation that benefits during times of declining credit spreads. Fixed-income arbitrage strategies purchase higher yielding bonds, which can be investment- or speculative-grade corporate bonds, mortgage-backed securities, or debt issued by emerging market governments. Higher quality debt is sold or leverage is acquired at lower rates. The strategy usually earns a positive income because the purchased bonds have a higher yield than the higher quality debt or the cost of the leverage. This strategy benefits when credit spreads are stable or tightening and markets are relatively liquid. Fixed-income arbitrage funds can suffer catastrophic losses during flight to quality markets because credit spreads widen quickly, leverage becomes more expensive, and markets for lower quality debt become much less liquid. 
Medium volatility hedge fund strategies typically take both long and short positions, but these positions are not always designed as hedges. The long and short positions may differ dramatically in size and/or risk, often resulting in a net long position in an underlying stock, bond, commodity, or currency market. These strategies have an average volatility of 10-12 percent per year, which is slightly less than the volatility of the underlying markets.

Global macro funds typically focus on long and short investments in broad markets, such as equity indices, currencies, commodities, and interest rate markets. Rather than selecting specific securities, macro funds focus on the macroeconomic picture, selecting asset classes and countries that will benefit from the manager's market view. In many cases, these views will be driven by market changes related to governmental actions, such as the transition from fixed to floating rate currencies. Macro funds can take concentrated positions and be quite volatile. Because macro fund managers have the entire world of securities to choose from, they tend to be difficult to replicate and have a relatively low correlation with other managers trading the same strategy.

Long-short equity funds are the largest hedge fund strategy, earning nearly 40 percent of all investor dollars allocated to hedge funds. The implementation is very similar to that of equity market neutral hedge funds, except that long-short funds do not target a zero beta exposure to underlying equity markets. During long periods of time, these funds may average a net long beta of 0.3 to 0.6 . When bear markets are expected, however, managers have the flexibility to take a neutral or short exposure to equity markets.

Managed futures funds, in which the managers are also called commodity trading advisers (CTAs), use a strategy dominated by systematic trend following that seeks to profit through the quantitative prediction of market trends. These funds will invest in currencies, commodities, equity indices, and interest rate futures. They seek to take long positions during times of rising prices and short positions during times of falling prices. Managed futures funds typically have no target for the mix of long and short positions but simply build a bottom-up portfolio of positions expected to benefit from the anticipated trends in market prices. Although the risk-return profile of the managed futures index does not seem to be attractive on a stand-alone basis, this strategy offers the best hedging and diversification characteristics of any hedge fund strategy. Valuation risk, liquidity risk, complexity risk, and counterparty risk are typically minimal in this sector.

Multistrategy funds are similar to funds of funds in that they diversify broadly among a variety of hedge fund strategies. A fund of funds invests with a number of underlying managers and charges a second layer of fees at the fund-of-funds level. Multistrategy funds charge only a single layer of fees but typically manage all of the assets with managers employed by a single hedge fund management company.

Directional hedge fund strategies are the most volatile of all because little to no hedging activity is used. As such, these strategies inherit the full volatility (15-17 percent or more) of the underlying markets in which the funds are invested.

Dedicated short bias funds typically invest exclusively in the short sale of equity securities. Although the funds often have a beta exposure close to -1.0 , their returns can add significant value if the manager displays skill in predicting which stocks will underperform the market index.

Emerging market hedge funds are often long only because the ability to trade derivative securities or sell short is either not developed or is prohibitively expensive in these markets. Although some funds may focus on specific regions or trade exclusively fixed-income or equity market funds, others may invest globally and mix stocks and bonds in the same fund. When the debt of emerging market countries is rated below investment grade, these bonds may have risk and return characteristics similar to equity securities.

\section{Hedge Fund Databases and Performance Biases}

Hamza, Kooli, and Roberge (2006), Fung and Hsieh (2004), and Malkiel and Saha (2005) describe a number of features of hedge fund databases. A variety of databases exist, including Hedge Fund Research (HFR), Credit Suisse/Tremont, MSCI, Lipper TASS, EACM, Zurich, Eurekahedge, Tuna, and Center for International Securities and Derivatives Market (CISDM). Although each database contains hundreds, or thousands, of hedge funds and their associated returns, no database is complete. In fact, a surprisingly high number of hedge funds report only to a subset of available databases. Many academics and large hedge fund investors subscribe to multiple databases to get a more complete picture of the hedge fund universe. 
Each hedge fund database provider has its own methodology for the inclusion of funds, style classification of funds, and the index weight. For example, HFR is equally weighted whereas Credit Suisse/Tremont is asset weighted. This difference in fund weighting methodology can lead to substantial differences in hedge fund index returns, risks, and correlations across databases. Although equally weighted databases are more representative of the "average" hedge fund, this methodology places a larger weight on funds with lower levels of assets under management (AUM). Equally weighted databases also require a rebalancing methodology, which may not be feasibly implemented in a world with large minimum investments and substantial lockup periods. An asset weighted database places a larger weight on hedge funds with larger AUM, which leads the index to be more representative of the hedge fund industry than of the average hedge fund.

As a result of the lack of disclosure requirements by hedge funds, reporting to databases is voluntary. Some analysts believe that managers with higher returns and lower risks are more likely to report returns to database providers, whereas managers of funds with less attractive track records are less likely to provide their track record to the database. This lack of reporting leads to selection bias or self-reporting bias, in which the risk-return tradeoff of hedge funds represented by databases is more attractive than what is actually experienced by the full universe of hedge fund investors.

Selection bias is closely related to backfill bias, which is also termed instant history or incubation bias. When a manager decides to report to a database, he or she frequently does so after earning attractive returns for the first one to three years of managing the fund. Databases note the first month that the fund started to report returns but include the fund's entire track record as "backfilled" data. For example, a fund may choose to report to a database in December 2008 and send the fund's return history since its July 2007 inception. The first live month of performance would be December 2008, and the returns since July 2007 would be backfilled. Hamza, Kooli, and Roberge (2006) estimate that dropping the first two years of each fund's returns would reduce the returns to the average fund in the HFR database by 0.5 percent annually and by 1.4 percent per year in TASS. Malkiel and Saha (2005) estimate the size of the incubation bias to be 5.74 percent, where median backfilled returns exceed returns reported in real time. Many researchers are now using the database codes to analyze only returns reported live, discounting the performance during the backfilled period to get a more accurate estimate of hedge fund performance.

Survivor bias is a substantial topic of discussion in hedge fund literature as a result of the short average life time of hedge funds. Gregoriou, Hübner, Papageorgiou, and Rouah (2005) discuss the mortality of commodity trading advisers and report that the median fund survived only 4.4 years. Malkiel and Saha (2005) report that less than 25 percent of funds operating in 1996 were still reporting to databases in 2004. Because liquidated funds tend to have lower returns and higher risks than funds with continuing operations, a database in which the track records of nonsurviving funds are excluded will produce an analysis that suffers from survivor, or survivorship, bias. In the literature, authors report a wide range of estimates of survivor bias; the returns to live funds exceed the returns to the combination of live and defunct funds by between 0.6 percent and 3.6 percent per year. By not including failed funds in return calculations, hedge fund returns will be overstated by this amount.

Survivor bias is greatest in equally weighted indices and those without a listing of deceased, or graveyard, funds. This bias is substantially reduced when working with funds of funds, asset weighted indices, investible indices, and databases that continue to carry the returns of liquidated funds. Survivor bias and backfill bias are decreasing as the hedge fund industry matures, database methodologies are improved, and the AUM of hedge funds are increasingly concentrated among a smaller number of very large funds. Fung and Hsieh (2004) report that 25 percent of hedge funds manage more than 75 percent of the industry's AUM, and concentration has increased since their study. At the inception of a database, which is frequently between 1990 and 1994, backfill bias may be larger because all funds added at that time reported returns since the inception of each fund. Sharma (2004) reports that HFR and Credit Suisse/Tremont have minimal survivor bias because these databases retain the returns of liquidated funds in their index calculations. 
Hedge fund style indices may not be appropriate benchmarks, even for managers that profess to trade in a specific style. Besides the biases already discussed, funds within a specific trading style generally do not have homogenous trading algorithms and do not disclose their market exposures. Some styles with a limited opportunity set (e.g., risk arbitrage) or static market exposures (e.g., equity market neutral) will have a higher correlation and a lower return dispersion across funds. Other styles that provide a greater breadth of asset classes, trading strategies, and market exposures, such as global macro and multistrategy, will have a greater dispersion of returns and a lower correlation of returns across funds.

\section{Factor Models for Hedge Fund Returns}

Hedge fund investors must understand the risks they are taking and the fees they are paying. To evaluate the value added by a hedge fund, investors need to decompose returns into alpha (manager skill) and beta (market exposure). Ideally, hedge funds would earn returns uncorrelated with the investor's existing stock and bond portfolio (low beta), and the high fees paid to hedge funds would earn the investor returns composed entirely of alpha.

Hedge fund factor analysis is discussed by Kat (2004), Fung and Hsieh (2004), Beckers, Curds, and Weinberger (2007), and others. In a hedge fund factor model, a regression is performed to determine the portion of risk derived from the market and the value added by the hedge fund manager. The typical regression is

Hedge fund return $=$ Alpha + Risk free rate $+\sum_{i}$ Beta $_{i} \times$ Factor $_{i}$.

Notice that alpha in this model is the total return of the hedge fund in excess of the risk free rate and the included factor or market exposures. A misspecification of this model that omits relevant risk factors will overestimate alpha. For example, assume that the return to the S\&P 500 Index is included in the model and the resulting alpha is 5 percent per year. This alpha calculation assumes that the hedge fund is only taking on the risk of the price of large-capitalization U.S. based companies. If another significant risk factor is included, the alpha estimate will decline, so it is imperative to include all relevant risk factors.

Most models use a multitude of traditional market factors, such as local and global stock and bond indices, currency, and commodity market returns. Popular factors in the literature include the S\&P 500 Index, Russell 1000 and 2000 indices, Europe/Australasia/Far East Index, emerging market stock and bond indices, changes in high yield and investment grade credit spreads, and the slope of the U.S. Treasury yield curve. Notice that all of these traditional market factors are commonly included in investor portfolios and exposures can be achieved by using low-cost index funds. Traditional market risk factors explain 50-80 percent of the variation in hedge fund returns. Far from being pure alpha, market neutral, or absolute return investments, many hedge fund styles take significant risks in traditional market factors.

Some hedge fund strategies, especially those in the market neutral or arbitrage categories, typically take a lower exposure to traditional market factors, such as equity beta or bond market duration. Although a fund may take minimal factor exposure with traditional beta risks, many hedge fund styles focus on taking risks with exotic betas or hedge fund betas. These exotic beta exposures are typically not prevalent in most investor portfolios. Exotic betas could include equity market volatility, credit default swaps, spreads between large- and small-cap stock returns, and spreads between value and growth stocks. In the newest literature, authors are modeling hedge fund strategies as separate beta exposures and using a naive strategy to replicate returns to merger arbitrage or managed futures funds.

Dynamic betas can be replicated through the modeling of a trend following methodology, the purchase or sale of options on a variety of underlying markets, or the use of rolling window analysis. Fung and Hsieh (2004) found six significant factors in their analysis that explained 55 percent of the variation in the HFR fund-of-funds index from 1994 to 2002. The betas calculated from the factor analysis regression showed the hedge fund index's average exposure over time. Many hedge funds, however, do not have static beta exposures but vary their market exposures substantially over time. By splitting the sample into smaller time periods, such as January 1994 to 
September 1998 or April 2000 to December 2002, the $R^{2}$ of the regression climbed as high as 80 percent. Beckers et al. (2007) used a 36-month rolling window regression to explain the returns of funds of funds. Ideally, hedge funds will take greater exposure in rising markets and less exposure in declining markets. Unfortunately, these authors found evidence of negative market timing skill among fund-of-funds managers.

\section{Non-Normality of Hedge Fund Returns}

Much of the traditional finance literature has made the implicit assumption that investment returns are normally distributed and linearly related to asset class returns. Sharpe ratios and Markowitz's efficient frontier analysis include return and standard deviation of return in their calculations of risk-return trade-offs. The calculation of beta, and the resulting Jensen's alpha, include the assumption that investment returns are earned from taking risk exposures to traditional market factors and that these exposures are relatively constant through time. Unfortunately, many of these assumptions are violated when investing in hedge funds. Because hedge fund returns are often not normally distributed or linearly related to traditional market exposures, Kat (2003) and Cremers, Kritzman, and Page (2005) show that applying many of the classical techniques and ratios to hedge fund returns without accounting for nonlinearities can cause investors to reach inappropriate conclusions about the attractiveness of hedge funds. As a result, some investors allocate too much of their portfolio to hedge funds and are disappointed when their assumptions are violated.

The Sharpe ratio and efficient frontier analysis assume that standard deviation is the only investment risk, but many hedge fund strategies have return profiles in which the skewness and kurtosis of returns do not closely match the assumptions of the normal distribution. Investors prefer a large mean and positive skewness of returns, while also preferring lower variance and smaller kurtosis. Hedge funds generally have higher moment risks, in which returns have negative skewness (i.e., the third moment of the return distribution) and large excess kurtosis (i.e., the fourth moment of the return distribution, also called fat tails). These return characteristics come from managers' spread trading strategies, which Kat (2004) deemed to be "pseudo" arbitrages and showed that these trades are far from risk free. Because these trades typically have a low volatility, leverage is frequently used.

Consider a merger arbitrage trade in which the fund manager purchases the target company and sells short the acquiring company with the intention of earning a 10 percent return during the next 12 months. When the deal is consummated at the time and terms as expected, it seems to be a low risk, low volatility strategy. In actuality, this trade is selling insurance. Investors sell the target company at a discount to its stated deal price to hedge the risk that the deal will fail. By offering the hedge fund the last 10 percent of return, the investor avoids the risk of a one week decline of 30 percent or more in the target stock should the merger not proceed as planned. Notice that this trade is negatively skewed and highly kurtotic because the potential loss is larger than the potential gain and the losses come much more quickly than the gains.

Similar return profiles can be found in fixed-income arbitrage, option selling strategies, and currency carry trades. Evaluating the returns to these funds during quiet and converging market conditions can underestimate the potential losses that these funds could experience during turbulent markets in which credit spreads widen and stock prices decline quickly. Black (2006), Weisman (2002), and Kat (2003) demonstrate that these trading styles are short volatility, meaning these strategies incur substantial losses at times when equity market volatility is rising. Adding long volatility strategies, such as managed futures or purchased options, to a hedge fund portfolio can cause portfolio returns to be closer to normally distributed. When balancing long volatility and short volatility in a hedge fund portfolio, reported volatility will increase and the Sharpe ratio will decline but the skewness and kurtosis exposures will be much more attractive to investors. Much of the nonlinearities in hedge fund returns can be traced back to extreme events, such as the demise of Long-Term Capital Management in 1998 (see Kazemi and Schneeweis 2004). 


\section{Liquidity, Complexity, and Valuation Risks}

Hedge fund factor exposures vary in their ease of being added to a factor model compared with traditional market exposures, which are better understood and easy to add to a factor model. Hedge fund strategies and exotic betas are more difficult to derive, but once derived they are straightforward to add to the factor model. Some of the hedge fund returns attributed to alpha could simply be compensation for bearing liquidity and complexity risks. That is, some investments should offer higher returns simply because they are more difficult to understand or value.

Till (2004) discusses the costs of illiquidity in hedge funds. As mentioned earlier, investors should be compensated for longer lockup periods, and many hedge funds are now offering lower fees in exchange for investors agreeing to longer lockup periods. Investors should also be compensated for short volatility risk and event risk. Illiquid assets, such as emerging markets, over-the-counter derivatives, microcap stocks, and distressed fixedincome securities, are difficult to value and difficult to trade. Investors in these assets are taking the risk that the assets will be valued at a price far different from what would be realized when asking the market for liquidity. Should the hedge fund choose or be forced to sell during a liquidity crisis, prices will be even lower.

In these illiquid asset classes, many holdings are valued using a mark-to-model methodology. Because these assets do not have a liquid market, marking to market is not feasible. These assets also trade infrequently, so valuations change relatively slowly when compared with prices in more liquid markets. This tendency to change valuations slowly is termed stale pricing. When funds exhibit stale pricing, the risk of the fund's holdings will be understated because volatility and the correlation with freely traded assets are likely to be understated. Kat (2004) estimates that this artificial smoothing of net asset values can underestimate risk by as much as 40 percent. Although it seems logical to include illiquidity in a factor model, Kat (2004) states that no study has adequately modeled this common risk of hedge fund investing. The Sharpe ratio of funds with smoothed returns is dramatically overstated, as the standard deviation of reported returns is far below the true economic standard deviation.

Although it can be difficult to include illiquidity in a factor model, a number of authors have suggested adjustments to smoothed data to estimate the true, or unsmoothed, risk of these illiquid investments. Getmansky, Lo, and Makarov (2004) explain the procedures for adjusting for stale prices, which can be detected through the use of serial correlation. When analysis shows that autocorrelation is present in hedge fund returns, it is said that the returns have been smoothed and that prior month returns can be used to predict the current month returns. The factor analysis equation given earlier can be modified as follows:

Hedge fund return $(t)=$ Alpha + Risk free rate + Hedge fund return $(t-1)+\sum_{i}$ Beta $_{i} \times$ Factor $_{i}$.

By including the prior month's return, the analysis shows that this hedge fund trading strategy incurs illiquidity risks. When the prior month's return is statistically significant, a new explanatory factor is added to the analysis. The typical result is that the $R^{2}$ of the regression increases and the alpha of the hedge fund style declines. Some authors include lagged values of a hedge fund index or a traditional market beta source. When the current month and the prior month both have a statistically significant exposure to a given factor, Kazemi and Schneeweis (2004) show that the true risk to that factor is the sum of the current and prior month's factor betas. For example, rather than the fund beta being 0.3 from the S\&P 500 Index return in the current month, the true beta would be 0.5 if the regression also showed a statistically significant beta of 0.2 from the prior month's return on the S\&P 500 Index.

Getmansky, Lo, and Makarov (2004) show that stale pricing risks are most prominent in fixed-income and convertible bond strategies, as well as event driven and relative value strategies and emerging markets. These markets are known for their illiquidity and the need for mark-to-market valuation. Strategies that rely on trading in more liquid markets, such as large-cap stocks, currencies, and commodity futures, do not show evidence of stale pricing because fund managers can easily calculate NAV from each day's market settlement prices. 
Beyond the effect of underestimated risks, stale pricing can have clear financial implications for investors. If the monthly NAV for a hedge fund is struck using stale prices, investors who sell hedge fund interests during a bull market may receive proceeds of less than the fair value for those assets. Conversely, investors who redeem hedge fund interests during a bear market will receive a higher than realistic price for their assets because future prices are likely to be lower when full markdowns of assets are taken.

\section{Alpha and the Capacity for Hedge Funds to Increase Assets}

Géhin and Vaissié (2006) and Amenc and Martinelli (2002) discuss the proper calculation of the alpha earned by hedge funds. Alpha is the return to the hedge fund after accounting for the risks incurred by both traditional and alternative beta exposures. Amenc and Martinelli (2002) estimate the alpha of hedge funds to be 5.8 percent per year in excess of the exposure to traditional beta risks. After adding the exposure to alternative beta risks, the alpha declines to -1.0 percent. The implication of this analysis is that hedge funds, as a group, do not earn positive alpha but simply provide investors with the ability to access alternative beta exposures.

Of course, alpha varies over time and by strategy. Concerns exist that as the size of the hedge fund industry increases, the alpha earned by the average hedge fund will decline. More simply, Hsieh (2006) estimates that by exploiting market inefficiencies a static $\$ 30$ billion in alpha is available to be earned by all hedge fund managers combined. This amount is based on 3 percent alpha from a hedge fund industry size of $\$ 1$ trillion, but as hedge fund assets grow to $\$ 2$ trillion, the percentage return to each fund in alpha terms would decline to 1.5 percent. This argument assumes that a finite capacity for AUM for hedge funds exists, both as an industry and in each strategy. As greater assets enter each strategy, the market inefficiencies disappear more quickly, making the future prognosis for hedge fund growth dim. Géhin and Vaissié (2006), however, find no clear evidence of a declining trend in alpha. The capacity for hedge fund managers to profitably invest is based on alpha and beta factors. If hedge funds derive most of their returns from beta factors, then the industry can continue to grow in terms of assets and managers. If hedge funds are dependent on alpha and disappearing market inefficiencies, then the capacity of AUM for the hedge fund industry is more limited.

Géhin and Vaissié (2006) believe that investors overstate the importance of alpha and understate the importance of beta when analyzing the returns to hedge funds. The three drivers of hedge fund returns are static beta exposures, dynamic beta exposures (market timing), and alpha (security selection skill). The authors estimate that approximately half of hedge fund variance comes from static betas, whereas the remaining variance is evenly split between dynamic betas and alpha. Nearly the entire return to hedge funds can be attributed to static betas, whereas dynamic betas incur losses over time and alpha adds value.

\section{Hedge Fund Replication}

Hedge fund replication is widely discussed in the literature, with Jaeger and Wagner (2005), Fung and Hsieh (2004), and Kat (2007) leading the discussion. The original discussion of hedge fund replication was based on the factor models mentioned earlier and the concept of alpha-beta separation. If traditional stock and bond market indices can explain the majority of hedge fund return variance, then investors may be able to replicate hedge fund returns by using index funds and swaps products. Replication strategies can be attractive when hedge fund managers are not earning a positive alpha, when investors are worried about the size of the fees paid to hedge fund managers, or because of the historical lack of liquidity and transparency of hedge fund investments. A common theme in the replication literature is that replication products are relatively simple to manage and can, therefore, be offered to investors at fees much lower than those charged by hedge fund managers.

The simplest form of replication uses static weights to invest in traditional market products. Jaeger and Wagner (2005) develop replicating factor strategies, which can replicate many hedge fund styles with just three or four traditional market exposures. Of 11 styles tested, 8 could be replicated with an $R^{2}$ above 49 percent. Long-short equity, emerging market, short selling, and distressed strategies can be most closely replicated, with an $R^{2}$ of between 68 percent and 88 percent. Less efficient replications can be developed for equity market neutral, 
risk arbitrage, fixed-income arbitrage, convertible bond arbitrage, global macro, and managed futures strategies. For example, a simple replication of a fixed-income arbitrage fund would take a long position in a credit fund, such as corporate bonds, high yield bonds, or mortgage-backed securities, and a short position in a Treasury securities fund of a similar duration. The weights for each fund would be determined through a linear regression of long-term hedge fund returns on the traditional bond market sector funds. A slightly more complex form of replication uses dynamic weights with the same traditional market factors. Rather than having static weights, the beta exposure to each market sector is determined through the use of rolling regressions, with common look back periods of one to three years.

Fung and Hsieh (2004) add dynamic strategies to the factor mix, simulating the use of look back straddles on bond, currency, and commodity indices. These dynamic factors can simulate the use of trend following strategies, as well as short or long volatility exposures.

Berger, Crowell, and Kabiller (2008) seek to separate hedge fund beta from hedge fund replication. Hedge fund replication using factor models and liquid index products avoids many of the issues of liquidity and complex valuation faced by hedge funds that invest in specific securities. To capture the returns to event risk, illiquidity, and complex securities, the hedge fund beta strategy seeks to mechanically reproduce hedge fund strategies by investing in specific securities. A fund designed to provide merger arbitrage beta, for example, would purchase the target company and sell short the acquiring company in all announced merger transactions. Beta exposure to managed futures could be developed through a mechanical trend following system that seeks to buy futures in any market with a trend of rising prices and sell short futures in any market in which prices are expected to decline. A distressed or convertible arbitrage beta could be devised through the purchase of those specific fixed-income securities, perhaps by selling short the related equity security.

\section{Hedge Fund Portfolio Analysis}

Hedge fund investors are interested in how an allocation to hedge funds would modify the risk and return of their entire portfolio, including exposures to traditional stock and bond markets. Fund-of-funds managers are concerned with building the most efficient portfolio of hedge funds. In each case, the goal is to minimize the risk for each level of expected return. Ideally, adding hedge funds to a traditional investment portfolio would reduce portfolio risk without reducing portfolio return.

Traditional portfolio theory says that the calculation of efficient portfolios requires estimates of return, correlation, and volatility for each asset class. The factor analysis techniques discussed earlier can give clues to future correlation and volatility. For example, long-short equity funds are highly correlated with stock market indices in which volatility is scaled by the average beta through time. Géhin and Vaissié (2006) state that managed futures, fixed-income and convertible bond arbitrage, and market neutral equity funds provide the best diversification properties when added to an equity portfolio. Similarly, event driven, long-short equity, emerging market, and convertible bond arbitrage funds add diversification to a fixed-income portfolio.

Allison and Lin (2004) show that a number of caveats exist when attempting to model the addition of hedge funds to traditional portfolios. Specifically, it is difficult to develop expected return assumptions for hedge funds given the survivor, selection, stale pricing, and backfill biases inherent in hedge fund databases. Correlation and volatility of historical hedge fund returns, however, can be appropriately used to develop estimates of future risks. After determining the beta of each hedge fund strategy in relation to the underlying traditional market factors, an expected return assumption for the hedge fund style can be derived by adding estimated alpha to the beta adjusted expected returns of the underlying asset classes.

Dopfel (2005) also uses the alpha and beta estimates of factor analysis to derive expected returns for hedge fund strategies. Investors need to be aware, however, that hedge fund performance can be quite dynamic, with correlation, volatility, and beta exposures that can change significantly over time. In addition, derivatives and short volatility trading strategies can add nonlinearities to the hedge fund return generation process. These properties can lead hedge funds to have asymmetrical beta exposures, in which the beta of the hedge fund differs according 
to the volatility and the direction of the underlying market. For example, managed futures and dedicated short bias funds have attractive asymmetrical exposures to equity index prices, with higher betas in rising markets and lower betas in falling markets. Multistrategy and market neutral equity funds have little exposure to asymmetrical beta. Unfortunately, all other hedge fund styles have negative asymmetrical beta exposures, and betas tend to rise in falling markets. Dopfel (2005) also discusses using factor analysis to target overall asset allocation. When the hedge fund portfolio has a persistent beta relative to equity markets, it is wise to reduce the portfolio's exposure to equity markets by a similar amount to ensure that equity market risk is consistent with the strategic asset allocation.

Kat (2004) warns about the use of mean-variance optimization and Sharpe ratios in building hedge fund portfolios because standard deviation is not a complete measure of risk for hedge funds. Some hedge fund styles are known to smooth returns, as well as experience negative skewness and excess kurtosis. In fact, the hedge fund styles with the lowest standard deviations and highest Sharpe ratios are often the ones with the most unattractive higher moment exposures. A high Sharpe ratio and high alpha are simply invitations to further research the hedge fund manager's trading strategy. Investors need to determine whether the trading strategy is a short volatility, convergence related, or event-risk-laden strategy in which future risks could potentially be larger than historical risk. The typical result of adding hedge funds to a portfolio of traditional investments is that standard deviation will decline and the Sharpe ratio will increase but at the cost of worsening higher moment exposures. This result is attributed to the variable correlation and asymmetrical beta exposures of hedge funds, in which losses to hedge fund portfolios tend to increase during times of extreme losses in stock and bond markets. Mean-variance optimization also assumes that assets have the same liquidity characteristics and return distributions. If mean-variance optimization is to be used to add hedge funds to traditional investment portfolios, constraints on the deterioration of skewness and kurtosis risks should be added to the optimization equation. Placing constraints on the nonlinearities of hedge funds will cause investors to choose lower allocations to hedge funds than when mean-variance optimization is used without considering higher moment risks.

Sharma (2004) states that higher moment risks are more prevalent in lower volatility strategies because 75 percent of nondirectional strategies have returns that are not normally distributed, whereas only 39 percent of directional strategies reject normality.

Kat (2004) discusses the differences in analyzing hedge fund index data and the returns to individual hedge funds. Individual hedge funds typically have a higher standard deviation than their style index because a less than perfect correlation exists between funds in the same style. When aggregating hedge funds into a style index, the standard deviation of the index is lower than the standard deviation of the average fund, but the index tends to have more negative skewness and a higher correlation with equity markets. Although each fund has its own specific risks and market timing, those exposures are averaged when funds are bundled into an index. Although it diversifies the specific risk of each fund, the indexing process reduces standard deviation but increases the exposures to common factor risks.

\section{Performance Persistence of Hedge Funds}

Beckers et al. (2007) discuss the performance persistence of hedge funds and find that the persistence of alpha is higher than the persistence of total returns. The persistence of funds with high information ratios (i.e., alpha divided by the standard deviation of alpha) is greater than that of funds with high Sharpe ratios. Specifically, funds with top quartile rankings of information ratios during the trailing three years have a 51 percent chance of remaining in the top quartile of that same measure during the subsequent year. Persistence is also strong for lower quartile funds because a large percentage of funds repeat as below average performers. Funds of funds show much greater persistence than single strategy hedge funds. The common factor risks tend to dominate the performance of single strategy funds, which are often clustered around the average return for the strategy. Funds of funds diversify among hedge fund styles, which diversifies the risks of relying on returns from a specific market factor. 
Naik and Agarwal (2000) analyzed the performance persistence of hedge funds by calculating the alpha of each fund relative to its style index using quarterly returns. Past performance was calculated by using a variety of methodologies, including regressions, contingency tables, and appraisal ratios, which explicitly consider volatility and leverage. The results indicated that persistence varies by hedge fund style because 6 to 8 of 13 strategies showed reasonable persistence using different methodologies. Losers tend to exhibit greater persistence than winners, which shows the importance of manager selection when building a portfolio of hedge funds.

\section{Funds of Funds}

Funds of funds allow investors to one-stop shop for their hedge fund needs at a low minimum investment. Fothergill and Coke (2001) describe the advantages and disadvantages of investing in funds of funds. Funds of funds use investment managers that perform due diligence on single strategy hedge fund investments, with the goal of building a lower risk, well-diversified hedge fund portfolio. By investing in 15 to 20 single manager hedge funds across a variety of trading styles, funds of funds can reduce the standard deviation of a hedge fund portfolio. Smaller investors may be able to access a fund of funds portfolio with a minimum investment as low as $\$ 100,000$, far lower than the $\$ 7$ million to $\$ 20$ million required to meet the minimum investment requirements of each of the underlying hedge fund managers. Funds of funds may offer preferential liquidity terms to investors, perhaps allowing monthly redemptions, which are preferable to the quarterly or annual redemptions of the underlying managers.

Smaller investors may appreciate the due diligence performed by funds-of-funds managers because this task can require significant investment skill, manager relationships, and research costs. Of course, the funds-of-funds manager gets paid for providing access, diversification, risk management, and due diligence benefits to investors. A common fee structure requires a 1 percent management fee and a 10 percent performance fee to be paid to the funds-of-funds manager, which is in addition to the 2 percent and 20 percent fees paid to the underlying hedge fund managers. Beckers et al. (2007) calculate that the average fund-of-funds fee is 1.3 percent plus 8.1 percent. This double layer of fees presents a high hurdle for funds of funds to earn an alpha in excess of the required return for taking risks in the traditional and exotic beta exposures. The fund-of-funds business is becoming increasingly concentrated - the largest 25 percent of funds of funds manage more than 75 percent of all assets in this sector.

Funds of funds, as a result of their diversification among strategies and managers, tend to have average performance. Although single hedge fund managers and strategies will dominate the top and bottom of the performance charts, funds of funds tend to approximate hedge fund index performance before adding their second layer of fees. Beckers et al. (2007) show that the lowest quartile of funds of funds outperforms the lowest quartile of single manager funds (i.e., 6.3 percent versus 5.5 percent annually), whereas the top quartile of funds of funds offers lower returns than the top hedge funds (i.e., 15.1 percent versus 23.2 percent). Funds of funds also tend to have lower mortality, survivor bias, and backfill bias than single manager hedge funds. On average, funds of funds tend to add more value through risk reduction rather than return enhancement.

Funds of funds tend to take less factor risk than is found through the analysis of a broad hedge fund index. The typical hedge fund examined by Beckers et al. (2007) has an $R^{2}$ to traditional market factors of only 40 percent, but those common factor risks are rising over time. The authors find that even the lowest quartile of funds of funds earned alpha in excess of traditional market factor exposures, but exotic and hedge fund betas were not included in the analysis. Unfortunately, funds of funds have consistently taken common factor bets at the wrong time because beta exposures reduced returns in 8 of the 12 years of the study.

Hsieh (2006) explains that many funds of funds take substantial risk in traditional market factors. Investors in these beta funds may be paying high fees for risk exposures that can be sourced more cheaply outside of the hedge fund universe. Hsieh (2006) predicts that the limited number of funds of funds that provide true alpha with low beta risks will rapidly grow as a share of the industry's AUM, whereas funds of funds that provide beta exposures with minimal value added will struggle to retain market share. 
Fung, Hsieh, Naik, and Ramadorai (2008) calculated the alpha earned by funds of funds in three different time periods. Factor risks have statistically significant variations in exposure across three periods, with structural breaks at the time of the Long-Term Capital Management crisis and the end of the internet stocks era. They found that funds of funds did not earn statistically significant alpha between January 1995 and September 1998 or from April 2000 to December 2004. Funds of funds, however, did earn alpha from October 1998 to March 2000. Although the universe of hedge funds may not always earn alpha, some funds of funds always can. On average, 22 percent of funds of funds provided alpha, whereas the rest were simply providing factor exposures without value added. Of course, the portion of "have alpha" funds of funds varies over time, peaking at 42 percent in 2000.

Funds of funds with proven alpha tend to have longer lives and larger asset inflows. Unfortunately, the larger the inflows become, the more difficult it is to continue to earn high levels of alpha. Capital flows to alpha funds, presumably from sophisticated institutional investors, are relatively constant. Capital flows to beta funds are cyclical, with large flows from individual investors after times of high returns.

\section{Risk Management}

Some funds of funds will closely manage their risks, especially to traditional beta exposures. Beta risks can be limited in the portfolio construction process by closely understanding the beta exposures of individual hedge fund managers and increasing the allocation to funds with lower market risks. Alternatively, the funds of funds will allocate to managers with the highest alpha and then hedge away the common factor risks at the fund-of-funds level. Hedging can be accomplished through the use of futures that linearly reduce market risks. Equity index options are also used, which reduce downside risks of the portfolio without capping the upside return potential.

Beyond market risks, hedge fund investors need to understand and manage a number of other risks. These include event risk, operational risk, leverage, and counterparty risks. In fact, many of these risks tend to magnify market risks, so a global view of risk is very important for hedge fund investors and fund-of-funds managers.

Event risks are commonly focused in event driven funds, such as those following mergers and distressed or special situation investments. Although event driven funds may offer a lower correlation with market indices, their returns can change dramatically at the emergence of event risk, such as when a merger deal is not completed or when a company defaults on debt that the manager assumed was issued by a going concern. Event risk can also be present in a number of other hedge fund styles, either from hedge fund managers explicitly including event driven investments in their fund or from the effect that specific events may have on broader market risks.

Operational risks can lead to a total loss of investments in a specific hedge fund. Kundro and Feffer (2003, 2004) estimate that 54 percent of hedge fund failures can be attributed, at least in part, to operational risks. Of the funds that failed as a result of operational failures, they estimate that 6 percent of occurrences were because of inadequate resources, 14 percent were the result of unauthorized trading and style drift, 30 percent were from the theft of investor assets, and 41 percent were from the misrepresentation of investments and performance. Further, they estimate that 38 percent of hedge fund failures had only investment risk, meaning that the operational controls were in place and effective. Surprisingly, 54 percent of hedge fund failures were the result of operational risk, whereas the final 8 percent of hedge fund debacles could be attributed to business risk or a combination of different risks.

In a series of case studies, Black (2007) shows that a key way to minimize operational risks is to ensure a strict delineation of duties within a hedge fund. This structure means the portfolio manager is separate from the risk manager, the pricing process, and the auditing function. A proper system of checks and balances ensures that the hedge fund manager stays within the risk limits stated in the hedge fund documentation. Ideally, a hedge fund should be diversified among securities and have leverage and market exposure limits consistent with a low probability of catastrophic losses. The valuation of securities should be handled outside of the portfolio management group to ensure accurate statements of risk and return. The auditing of returns should be handled by a reputable third party because the misstatement of hedge fund returns can prolong fraudulent behavior and allow a manager to continue to attract assets from new investors. Clearly, assets should be appropriately 
segregated—client funds should be kept safe and separate from the hedge fund's corporate and the manager's personal accounts. Many hedge fund investors insist on separate accounts or managed accounts in which the assets are held in custody with the investor's broker. The investor allows the manager to trade his or her account, but the complete transparency disallows excessive concentration or leverage risks that can cause catastrophic losses. A separate account format also prevents the misstatement of investment performance or the theft of client assets. Many investors perform a background check on hedge fund managers to ensure that the biography is correct and that the manager has not previously been disciplined by regulatory authorities or sued by prior investors.

Brown, Goetzmann, Liang, and Schwarz (2009) derive a quantitative operational risk score, $\omega$, that can be calculated from information in hedge fund databases. This quantitative factor score can be used as a supplement for qualitative due diligence, which includes manager interviews, on-site visits, and background checks. The score is used to define "problem funds" that subsequently have lower mean returns, lower Sharpe ratios, lower incentive fees, and less frequent high-water mark provisions than nonproblem funds. Similar to Altman's (1968) $z$-score, which is used to predict corporate bankruptcies, the $\omega$-score can be used to predict operational risks and the demise of hedge funds because the half-life of funds with an $\omega$-score exceeding one is just 4.2 years. Funds with lower returns, higher standard deviations, and lower incentive fees have characteristics that correlate with operational issues, such as conflicts of interests, concentrated ownership of the management company, relationships with investment advisers or broker/dealers, and the ability of fund staff to trade the same securities as the fund.

Counterparty risk arises whenever a hedge fund deals with investors, prime brokers, and other market participants. In the over-the-counter market, counterparty risk arises when a hedge fund is owed money on a swaps or options contract but the seller of the contract fails to deliver the required investment gains. Counterparty risk to prime brokers or investors is less obvious to discern but just as important.

A special concern is leverage that can magnify market risk and counterparty risk. Leverage allows a hedge fund manager to take economic exposure in excess of the assets invested by clients. Leverage can be explicit debt, borrowed either in the repurchase market or from a prime broker. For example, a fund with $\$ 100$ million in client assets may be allowed to borrow $\$ 900$ million and invest the entire $\$ 1$ billion fund value in fixed-income securities. When the return to the investment exceeds the borrowing costs, returns are increased through leverage. Of course, losses are also magnified. So, a 10 percent loss on the $\$ 1$ billion investment will cause a 100 percent loss of the clients' $\$ 100$ million investment. Leverage can also be gained through the use of derivative products, such as swaps, options, and futures, which can increase market exposure with initial capital requirements ranging from 0 to 20 percent of the notional value of the investment.

Sharma (2004) describes the dangers of leverage and the interaction between leverage, counterparty risk, and market risk. Leverage increases the probability of large investment losses because the increase in assets beyond investor capital magnifies the beta of the investment portfolio. Leverage also increases the vulnerability to margin calls and forced liquidations. Counterparty risk and leverage are a dangerous mix because the prime broker sets the credit limit for each hedge fund. For example, consider the fund mentioned earlier that invested $\$ 1$ billion based on only $\$ 100$ million in investor capital. If the prime broker reduces the credit limit from $\$ 900$ million to $\$ 400$ million, the fund manager is required to sell half of the fund's assets in just a few days' time. Credit limits are typically reduced during turbulent markets when it is difficult to sell assets for their fair value. This forced liquidation can be sufficient to cause catastrophic losses for the hedge fund because rapidly selling assets in a falling market can incur market impact sufficient to wipe out the investors' equity in the fund. Investor redemptions can also cause forced liquidations because managers are forced to sell assets in less than 30 to 60 days to return investor capital on a timely basis.

It is important for hedge fund managers to align the lockup policies of the fund with the liquidity of the underlying assets and the terms of financing used in the investment strategy. A fund of funds offering monthly liquidity to investors but investing in hedge funds with an average lockup period of two years is a recipe for a liquidity crisis that can cause dramatic losses to a fund. 


\section{Conclusion}

When allocating assets to hedge funds, investors need to clearly understand the characteristics of these investments. It is important to delineate the differences between fund strategies and to understand the level and volatility of the resulting alpha and beta exposures. This analysis can show the value added by the fund manager, as well as the fit between the hedge fund investments and the investor's traditional investments in equity and fixed-income securities. Beyond market risks, investors also need to investigate fee structures, operational risks, and the capacity of the market to absorb increased levels of hedge fund assets. 


\section{References}

Editor's Note: References mentioned in the text are marked with an asterisk.

Ackermann, Carl, Richard McEnally, and David Ravenscraft. 1999. "The Performance of Hedge Funds: Risk, Return, and Incentives." Journal of Finance, vol. 54, no. 3 (June):833-874.

"Hedge funds display several interesting characteristics that may influence performance, including flexible investment strategies, strong managerial incentives, substantial managerial investment, sophisticated investors, and limited government oversight. Using a large sample of hedge fund data from 1988-1995, we find that hedge funds consistently outperform mutual funds, but not standard market indices. Hedge funds, however, are more volatile than both mutual funds and market indices. Incentive fees explain some of the higher performance, but not the increased total risk. The impact of six data-conditioning biases is explored. We find evidence that positive and negative survival-related biases offset each other." (p. 833)

Agarwal, Vikas, and Narayan Y. Naik. 2000. "Multi-Period Performance Persistence Analysis of Hedge Funds." Journal of Financial and Quantitative Analysis, vol. 35, no. 3 (September):327-342.

"Since hedge funds specify significant lockup periods, we investigate persistence in the performance of hedge funds using a multi-period framework in which the likelihood of observing persistence by chance is lower than that in the traditional two-period framework. Under the null hypothesis of no manager skill (no persistence), the theoretical distribution of observing wins or losses follows a binomial distribution. We test this hypothesis using the traditional two-period framework and compare the findings with the results obtained using our multi-period framework. We examine whether persistence is sensitive to the length of return measurement intervals by using quarterly, halfyearly and yearly returns. We find maximum persistence at the quarterly horizon indicating that persistence among hedge fund managers is short-term in nature. It decreases as one moves to yearly returns and this finding is not sensitive to whether returns are calculated on a pre- or post-fee basis suggesting that the intra-year persistence finding is not driven by the way performance fees are imputed. The level of persistence in the multi-period framework is considerably smaller than that in the two-period framework with virtually no evidence of persistence using yearly returns under the multi-period framework. Finally persistence, whenever present, seems to be unrelated to whether the fund took directional bets or not." (p. 327)

- 2004. "Risks and Portfolio Decisions Involving Hedge Funds." Review of Financial Studies, vol. 17, no. 1 (Spring):63-98.

"This article characterizes the systematic risk exposures of hedge funds using buy-and-hold and option-based strategies. Our results show that a large number of equity-oriented hedge fund strategies exhibit payoffs resembling a short position in a put option on the market index and, therefore, bear significant left-tail risk, risk that is ignored by the commonly used mean-variance framework. Using a mean-conditional value-at-risk framework, we demonstrate the extent to which the mean-variance framework underestimates the tail risk. Finally, working with the systematic risk exposures of hedge funds, we show that their recent performance appears significantly better than their long-run performance." (p. 63) 
* Allison, Douglas T., and Felix T. Lin. 2004. "Including Hedge Funds in Private Client Portfolios." AIMR Conference Proceedings: Integrating Hedge Funds into a Private Wealth Strategy (February):6-20.

"Hedge funds can play a vital role in client portfolios, but clients need to be aware of all the issues involved-issues ranging from the impact of incorporating hedge funds into the portfolio mix to understanding the potential risks involved to the pros and cons of hedge fund investing. Once the decision has been made to include hedge funds in the portfolio mix, the allocation must be determined and should be based on future expectations for hedge fund performance. Finally, by using an optimizer, an ideal mix of hedge fund strategies can be established. The end result is a portfolio that meets client goals and objectives and has the potential to decrease risk and enhance return." (p. 6)

*Altman, Edward I. 1968. "Financial Ratios, Discriminant Analysis and the Prediction of Corporate Bankruptcy." Journal of Finance, vol. 23, no. 4 (September):589-609.

"Academicians seem to be moving toward the elimination of ratio analysis as an analytical technique in assessing the performance of the business enterprise. Theorists downgrade arbitrary rules of thumb, such as company ratio comparisons, widely used by practitioners. Since attacks on the relevance of ratio analysis emanate from many esteemed members of the scholarly world, does this mean that ratio analysis is limited to the world of 'nuts and bolts'? Or, has the significance of such an approach been unattractively garbed and therefore unfairly handicapped? Can we bridge the gap, rather than sever the link, between traditional ratio 'analysis' and the more rigorous statistical techniques which have become popular among academicians in recent years? The purpose of this paper is to attempt an assessment of this issue- the quality of ratio analysis as an analytical technique. The prediction of corporate bankruptcy is used as an illustrative case. Specifically, a set of financial and economic ratios will be investigated in a bankruptcy prediction context wherein a multiple discriminant statistical methodology is employed. The data used in the study are limited to manufacturing corporations.” (p. 589)

* Amenc, N., and L. Martinelli. 2002. "Portfolio Optimization and Hedge Fund Style Allocation Decisions." Journal of Alternative Investments, vol. 5, no. 2 (Fall):7-20.

"This paper attempts to evaluate the out-of-sample performance of an improved estimator of the covariance structure of hedge fund index returns, focusing on its use for optimal portfolio selection. Using data from $\mathrm{CSFB} /$ Tremont hedge fund indices, we find that ex-post volatility of minimum variance portfolios generated using implicit factor based estimation techniques is between 1.5 and 6 times lower than that of a value-weighted benchmark, such differences being both economically and statistically significant. This strongly indicates that optimal inclusion of hedge funds in an investor portfolio can potentially generate a dramatic decrease in the portfolio volatility on an out-of-sample basis. Differences in mean returns, on the other hand, are not statistically significant, suggesting that the improvement in terms of risk control does not necessarily come at the cost of lower expected returns." (p. 7)

Amin, Gaurav S., and Harry M. Kat. 2003. “Hedge Fund Performance 1990-2000: Do the 'Money Machines' Really Add Value?" Journal of Financial and Quantitative Analysis, vol. 38, no. 2 (June):251-274.

"In this paper we investigate the claim that hedge funds offer investors a superior risk-return tradeoff. We do so using a continuous time version of Dybvig's (1988a,1988b) payoff distribution pricing model. The evaluation model, which does not require any assumptions with regard to the return distribution of the funds in question, is applied to the monthly returns of 77 hedge funds and 13 hedge fund indices over the period May 1990-April 2000. The results show that as a stand-alone investment hedge funds do not offer a superior risk-return profile. We find 12 indices and 72 individual funds to be inefficient, with the average efficiency loss amounting to $2.76 \%$ per annum for indices and $6.42 \%$ for individual funds. Part of the inefficiency cost of individual funds can be diversified away. Funds of funds, however, are not the preferred vehicle for this as their performance appears to suffer badly from their double fee structure. Looking at hedge funds in a portfolio context results in a marked 
improvement in the evaluation outcomes. Seven of the 12 hedge fund indices and 58 of the 72 individual funds classified as inefficient on a stand-alone basis are capable of producing an efficient payoff profile when mixed with the S\&P 500. The best results are obtained when $10-20 \%$ of the portfolio value is invested in hedge funds." (p. 251)

* Anson, Mark J.P. 2001. "Hedge Fund Incentive Fees and the 'Free Option.” Journal of Alternative Investments, vol. 4 , no. 2 (Fall):43-48.

"One of the ironies of hedge fund investing is that investors can provide conflicting incentives to the hedge fund manager. While hedge fund managers earn a management fee, which is a constant percentage applied to the amount of assets managed in the hedge fund, they receive an incentive fee, which is a form of profit sharing when a profitable return is earned for their investors. The standard Black-Scholes analysis is used to determine the value of the call option on hedge fund incentives. The article also discusses how this call option might provide an inconsistent incentive compared to the desires of investors in the hedge fund." (p. 43)

Asness, Clifford. 2004. "Sources of Change and Risk for Hedge Funds." CFA Institute Conference Proceedings: Challenges and Innovation in Hedge Fund Management (August):4-9.

"A lot of change is on the horizon for hedge funds, particularly given institutional investors' growing use of alternative investments. The changes will likely bring a greater focus on benchmarking, calls for increased transparency, a need for better articulation of investment strategies, rationalization of hedge fund fees, and the need for solid risk control mechanisms. The future also brings subtle shifts in hedge fund risk. And although the risk of blowups still exists, perhaps the larger future risk will relate to diminished returns." (p. 4)

* _ 2006. “The Future Role of Hedge Funds." CFA Institute Conference Proceedings Quarterly, vol. 23, no. 2 (June):1-9.

"Hedge funds generate returns through managers' skill (measured by alpha) as well as managers' systematic risk taking (measured by hedge fund beta). Hedge funds combined with index funds are now poised to replace traditional active management. To position themselves for such a future role, hedge funds must correct some of the industry's negative characteristics, including high correlations with the market, the misuse of momentum strategies, and lags in marking to market. To appeal to institutional investors, hedge funds must also improve their professionalism by altering the way they make decisions, reducing their fees (or at least rationalizing them), and striving for increased transparency.” (p. 1)

Asness, Clifford, Robert Krail, and John Liew. 2001. "Do Hedge Funds Hedge?” Journal of Portfolio Management, vol. 28 , no. 1 (Fall):6-19.

"Many hedge funds claim to provide significant diversification for traditional portfolios, besides attractive returns. The authors provide empirical evidence regarding the return and diversification benefits of hedge fund investing using the CSFB/Tremont hedge fund indexes over 1994-2000. Like many others, they find that simple regressions of monthly hedge fund excess returns on monthly $S \& P$ 500 excess returns seem to support the claims about the benefits of hedge funds. The regressions show only modest market exposure and positive added value. This type of analysis can produce misleading results, however. Many hedge funds hold, to various degrees and combinations, illiquid exchangetraded securities or difficult-to-price over-the-counter securities. For the purposes of monthly reporting, hedge funds often price these securities using either the last available traded prices or estimates of current market prices. These practices can lead to reported monthly hedge fund returns that are not perfectly synchronous with monthly S\&P 500 returns. Non-synchronous return data can lead to understated estimates of actual market exposure. When the authors apply standard techniques 
that account for this problem, they find that hedge funds in the aggregate have significantly more market exposure than simple estimates indicate. Furthermore, after accounting for this increased market exposure, they find that taken as a whole the broad universe of hedge funds does not add value over this period." (p. 6)

* Beckers, Stan, Ross Curds, and Simon Weinberger. 2007. "Funds of Hedge Funds Take the Wrong Risks." Journal of Portfolio Management, vol. 33, no. 3 (Spring):108-121.

"On average, the funds of hedge funds industry over the last 15 years has delivered alpha with a high information ratio. Unfortunately, these alphas come with significant common-factor exposures for which the typical fund was unrewarded. While funds of hedge funds can deliver a valuable product, sloppy manager selection and portfolio construction typically result in less-than-pure alpha generation. A naive selection of a fund of hedge funds may thus lead to assuming relatively expensive commonfactor exposure without necessarily accessing significant skill-based returns. A multifactor modeling of fund of hedge fund returns can help to identify skillful value-added." (p. 108)

* Berger, A., B. Crowell, and D. Kabiller. 2008. "Is Alpha Just Beta Waiting to be Discovered? What the Rise of Hedge Fund Beta Means for Investors.” AQR Capital Management, Working paper (July): www.aqrcapital.com/ research_15.htm.

"Alpha is shrinking, and it's good news for investors. This idea may seem paradoxical. But alpha is really just the portion of a portfolio's returns that cannot be explained by exposure to common risk factors (betas). With the emergence of new betas, the unexplained portion (alpha) shrinks-alpha gets reclassified as beta. The rise of a group of risk factors we call hedge fund betas makes this transformation especially relevant today. Hedge fund betas are the common risk exposures shared by hedge fund managers pursuing similar strategies. We believe these risk factors can capture not just the fundamental insights of hedge funds, but also a meaningful portion of their returns. Hedge fund betas are available for investment and can also be used to enhance portfolio construction and risk management. Ultimately, we believe the rise of hedge fund betas will lead not only to the reclassification of alpha, but also to better-diversified portfolios with greater transparency, improved risk control, and - perhaps most importantly—higher net returns." (p. 1)

* Black, K. 2004. Managing a Hedge Fund: A Complete Guide to Trading, Business Strategies, Risk Management and Regulations. New York: McGraw-Hill.

This book covers an extensive array of topics concerning hedge funds, including a discussion of the impact of hedge funds on portfolios, measuring the performance of hedge funds, managing the risks of hedge funds, and appropriate hedge fund due diligence.

* _ . 2006. "Improving Hedge Fund Risk Exposures by Hedging Equity Market Volatility, or How the VIX Ate My Kurtosis.” Journal of Trading, vol. 1, no. 2 (Spring):6-15.

"In 2004 investors began trading futures on the volatility index (VIX). Investors can directly trade the volatility implied in stock index options. Because the VIX has a negative correlation to the S\&P 500 Index and most hedge fund styles, we find that adding a small VIX position to an investment portfolio significantly reduced portfolio volatility. This strategy may be more effective at improving the robustness of Sharpe ratios than other methods explored in the literature. Even more important, VIX rises quickly during the most risky market conditions, which dramatically improves the skewness and kurtosis characteristics of many hedge fund strategies.” (p. 6)

* _ . 2007. "Preventing and Detecting Hedge Fund Failure Risk through Partial Transparency." Derivatives Use, Trading Regulation, vol. 12, no. 4 (February):330-341.

"Some hedge fund investors may pay close attention to market risk while not spending enough time considering operational risks. The examples of Bayou, Wood River, and Lancer are used to illustrate 
the operational risks that are all too present in hedge funds. A proposal to gather and aggregate data directly from brokers and custodians could reveal a large portion of the data necessary to make wellinformed risk management decisions. Investors do not really need to know the details of every position owned by a hedge fund. They only need to see the partial transparency of aggregated risk statistics. A risk management system that is less intrusive to managers and more useful to investors could be an invaluable tool to fight hedge fund fraud." (p. 330)

Brooks, Chris, and Harry M. Kat. 2002. "The Statistical Properties of Hedge Fund Index Returns and Their Implications for Investors.” Journal of Alternative Investments, vol. 5, no. 2 (Fall):26-44.

"The monthly return distributions of many hedge fund indices exhibit highly unusual skewness and kurtosis properties as well as first-order serial correlation. This has important consequences for investors. Although many hedge fund indices are highly attractive in mean-variance terms, this is much less the case when skewness, kurtosis and autocorrelation are taken into account. Sharpe ratios will substantially overestimate the true risk-return performance of (portfolios containing) hedge funds. Similarly, mean-variance portfolio analysis will overestimate the benefits of including hedge funds in an investment portfolio and, therefore, overallocate to hedge funds. We also find substantial differences between indices that aim to cover the same type of strategy. Investors' perceptions of hedge fund performance and value added will, therefore, strongly depend on the indices used." (p. 26)

Brown, Stephen J., and William N. Goetzmann. 2003. "Hedge Funds with Style." Journal of Portfolio Management, vol. 29 , no. 2 (Winter):101-112.

"The popular perception is that hedge funds follow a reasonably well-defined market-neutral investment style. Investigation of the monthly return history of hedge funds over 1989-2000, however, finds there are in fact distinct styles of management that account for about $20 \%$ of the cross-sectional variability in performance. This result is consistent across the years in the sample and robust as to the way investment style is determined. Appropriate style analysis and style management are crucial to success for investors looking to invest in hedge funds.” (p. 101)

Brown, Stephen J., William N. Goetzmann, and Roger G. Ibbotson. 1999. "Offshore Hedge Funds: Survival and Performance, 1989-95.” Journal of Business, vol. 72, no. 1 (January):91-117.

"We examine the performance of the off-shore hedge fund industry over the period 1989 through 1995 using a database that includes both defunct and currently operating funds. The industry is characterized by high attrition rates of funds, low covariance with the U.S. stock market, evidence consistent with positive risk-adjusted returns over the time, and little evidence of differential manager skill." (p. 91)

Brown, Stephen J., William N. Goetzmann, and James Park. 2001. "Careers and Survival: Competition and Risk in the Hedge Fund and CTA Industry.” Journal of Finance, vol. 56, no. 5 (October):1869-1886.

"Investors in hedge funds and commodity trading advisors (CTAs) are concerned with risk as well as return. We investigate the volatility of hedge funds and CTAs in light of managerial career concerns. We find an association between past performance and risk levels consistent with previous findings for mutual fund managers. Variance shifts depend upon relative rather than absolute fund performance. The importance of relative rankings points to the importance of reputation costs in the investment industry. Our analysis of factors contributing to fund disappearance shows that survival depends on absolute and relative performance, excess volatility, and on fund age." (p. 1869)

* Brown, Stephen J., William N. Goetzmann, Bing Liang, and Christopher Schwarz. 2009. "Estimating Operational Risk for Hedge Funds: The $\omega$-Score." Financial Analysts Journal, vol. 65, no. 1 (January/February):43-53.

"Using a complete set of U.S. SEC filing information on hedge funds (Form ADV) and data from the Lipper TASS Hedge Fund Database, the study reported here developed a quantitative model called the $\omega$-score to measure hedge fund operational risk. The $\omega$-score is related to conflict-of-interest issues, 
concentrated ownership, and reduced leverage in the Form ADV data. With a statistical methodology, the study further related the $\omega$-score to such readily available information as fund performance, volatility, size, age, and fee structures. Finally, the study demonstrated that although operational risk is more significant than financial risk in explaining fund failure, a significant and positive interaction exists between operational risk and financial risk." (p. 43)

Brunnermeier, Markus K., and Stefan Nagel. 2004. “Hedge Funds and the Technology Bubble.” Journal of Finance, vol. 59, no. 5 (October):2013-2040.

"This paper documents that hedge funds did not exert a correcting force on stock prices during the technology bubble. Instead, they were heavily invested in technology stocks. This does not seem to be the result of unawareness of the bubble: Hedge funds captured the upturn, but, by reducing their positions in stocks that were about to decline, avoided much of the downturn. Our findings question the efficient markets notion that rational speculators always stabilize prices. They are consistent with models in which rational investors may prefer to ride bubbles because of predictable investor sentiment and limits to arbitrage.” (p. 2013)

* Cremers, Jan-Hein, Mark Kritzman, and Sebastien Page. 2005. "Optimal Hedge Fund Allocations." Journal of Portfolio Management, vol. 31, no. 3 (Spring):70-81.

"Hedge funds have return peculiarities not commonly associated with traditional investment vehicles. They are more inclined to produce return distributions with significantly non-normal skewness and kurtosis. Investor preferences may be better represented by bilinear utility functions or S-shaped value functions than by neoclassical utility functions, and mean-variance optimization is thus not appropriate for forming portfolios that include hedge funds. Portfolios of hedge funds formed using both mean-variance and full-scale optimization, given a wide range of assumptions about investor preferences, reveal that higher moments of hedge funds do not meaningfully compromise the efficacy of mean-variance optimization if investors have power utility; mean-variance optimization is not particularly effective for identifying optimal hedge fund allocations if preferences are bilinear or Sshaped; and, contrary to conventional wisdom, investors with S-shaped preferences are attracted to kurtosis as well as negative skewness." (p. 70)

* Dopfel, Frederick E. 2005. “How Hedge Funds Fit.” Journal of Portfolio Management, vol. 31, no. 4 (Summer):9-20.

"Hedge funds fit in an institutional investor's portfolio only if one can evaluate how the inclusion of hedge fund strategies would improve the performance of the entire portfolio, after considering both beta and alpha characteristics. This is more challenging than it first appears because of the opaqueness and the complexity of most hedge fund strategies. The key is to identify institutional-quality hedge funds that permit a clear understanding of the normal portfolio and provide confidence in projecting a positive, pure alpha. If these conditions can be satisfied, there are two possible approaches to incorporating institutional-quality hedge funds: (1) hedge funds as an active overlay at the total portfolio level, or (2) hedge funds as portable alpha within a traditional asset class." (p. 9)

Edwards, Franklin R. 1999. "Hedge Funds and the Collapse of Long-Term Capital Management." Journal of Economic Perspectives, vol. 13, no. 2 (Spring):189-210.

"The Fed-engineered rescue of Long-Term Capital Management (LTCM) in September 1998 set off alarms throughout financial markets about the activities of hedge funds and the stability of financial markets in general. With only $\$ 4.8$ billion in equity, LTCM managed to leverage itself to the hilt by borrowing more than $\$ 125$ billion from banks and securities firms and entering into derivatives contracts totaling more than $\$ 1$ trillion (notional). When LTCM's speculations went sour in the summer of 1998, the impending liquidation of LTCM's portfolio threatened to destabilize financial markets throughout the world. Public policy response to LTCM should focus on risks of systemic fragility and ways in which bank regulation can be improved." (p. 189) 
Edwards, Franklin R., and Mustafa Onur Caglayan. 2001. “Hedge Fund Performance and Manager Skill.” Journal of Futures Markets, vol. 21, no. 11 (November):1003-1028.

"Using data on the monthly returns of hedge funds during the period January 1990 to August 1998, we estimate six-factor Jensen alphas for individual hedge funds, employing eight different investment styles. We find that about 25 percent of the hedge funds earn positive excess returns and that the frequency and magnitude of funds' excess returns differ markedly with investment style. Using sixfactor alphas as a measure of performance, we also analyze performance persistence over 1-year and 2 -year horizons and find evidence of significant persistence among both winners and losers. These findings, together with our finding that hedge funds that pay managers higher incentive fees also have higher excess returns, are consistent with the view that fund manager skill may be a partial explanation for the positive excess returns earned by hedge funds.” (p. 1003)

Eichengreen, Barry, and Donald Mathieson, eds. 1998. Hedge Funds and Financial Market Dynamics. Washington, DC: International Monetary Fund.

This book discusses many aspects of hedge funds, including their operations, the hedge fund industry, hedge fund market dynamics, regulation, and recent crises and hedge funds.

* Fothergill, Martin, and Carolyn Coke. 2001. "Funds of Hedge Funds: An Introduction to Multi-Manager Funds." Journal of Alternative Investments, vol. 4, no. 2 (Fall):7-16.

"In addition to the enhanced risk-return profile of funds of hedge funds, there are numerous additional structural benefits to investment in multi-manager hedge funds. This article both reviews the characteristics of various hedge fund strategies and emphasizes the unique structural characteristics of multi-manager hedge funds.” (p. 7)

Fung, William, and David A. Hsieh. 1997. "Empirical Characteristics of Dynamic Trading Strategies: The Case of Hedge Funds.” Review of Financial Studies, vol. 10, no. 2 (Summer):275-302.

"This article presents some new results on an unexplored dataset on hedge fund performance. The results indicate that hedge funds follow strategies that are dramatically different from mutual funds, and support the claim that these strategies are highly dynamic. The article finds five dominant investment styles in hedge funds, which when added to Sharpe's (1992) asset class factor model can provide an integrated framework for style analysis of both buy-and-hold and dynamic trading strategies." (p. 275)

309-331.

"In this paper, we provide a rationale for how hedge funds are organized and some insight on how hedge fund performance differs from traditional mutual funds. Statistical differences among hedge fund styles are used to supplement qualitative differences in the way hedge fund strategies are described. Risk factors associated with different trading styles are discussed. We give examples where standard linear statistical techniques are unlikely to capture the risk of hedge fund investments where the returns are primarily driven by non-linear dynamic strategies." (p. 309)

- 2000. "Performance Characteristics of Hedge Funds and Commodity Funds: Natural vs. Spurious Biases." Journal of Financial and Quantitative Analysis, vol. 35, no. 3 (September):291-307.

"It is well known that the pro forma performance of a sample of investment funds contains biases. These biases are documented in Brown, Goetzmann, Ibbotson, and Ross (1992) using mutual funds as subjects. The organization structure of hedge funds, as private and often offshore vehicles, makes data collection a much more onerous task, amplifying the impact of performance measurement biases. This paper reviews these biases in hedge funds. We also propose using funds of hedge funds to measure aggregate hedge fund performance, based on the idea that the investment experience of hedge fund investors can be used to estimate the performance of hedge funds." (p. 291) 
2001. "The Risk in Hedge Fund Strategies: Theory and Evidence from Trend Followers." Review of Financial Studies, vol. 14, no. 2 (Summer):313-341.

"Hedge fund strategies typically generate option-like returns. Linear-factor models using benchmark asset indices have difficulty explaining them. Following the suggestions in Glosten and Jagannathan (1994), this article shows how to model hedge fund returns by focusing on the popular 'trendfollowing' strategy. We use lookback straddles to model trend-following strategies, and show that they can explain trend-following funds' returns better than standard asset indices. Though standard straddles lead to similar empirical results, lookback straddles are theoretically closer to the concept of trend following. Our model should be useful in the design of performance benchmarks for trendfollowing funds." (p. 313)

* _ . 2004. "Hedge Fund Benchmarks: A Risk-Based Approach." Financial Analysts Journal, vol. 60, no. 5 (September/October):65-80.

"Following a review of the data and methodological difficulties in applying conventional models used for traditional asset class indices to hedge funds, this article argues against the conventional approach. Instead, in an extension of previous work on asset-based style (ABS) factors, the article proposes a model of hedge fund returns that is similar to models based on arbitrage pricing theory, with dynamic risk-factor coefficients. For diversified hedge fund portfolios (as proxied by indices of hedge funds and funds of hedge funds), the seven ABS factors can explain up to 80 percent of monthly return variations. Because ABS factors are directly observable from market prices, this model provides a standardized framework for identifying differences among major hedge fund indexes that is free of the biases inherent in hedge fund databases." (p. 65)

* Fung, William, David A. Hsieh, Narayan Y. Naik, and Tarun Ramadorai. 2008. "Hedge Funds: Performance, Risk, and Capital Formation.” Journal of Finance, vol. 63, no. 4 (August):1777-1803.

"We use a comprehensive data set of funds of funds to investigate performance, risk, and capital formation in the hedge fund industry from 1995 to 2004. While the average fund of funds delivers alpha only in the period between October 1998 and March 2000, a subset of funds of funds consistently delivers alpha. The alpha-producing funds are not as likely to liquidate as those that do not deliver alpha and experience far greater and steadier capital inflows than their less fortunate counterparts. These capital inflows attenuate the ability of the alpha producers to continue to deliver alpha in the future." (p. 1777)

* Géhin, Walter, and Mathieu Vaissié. 2006. "The Right Place for Alternative Betas in Hedge Fund Performance: An Answer to the Capacity Effect Fantasy.” Journal of Alternative Investments, vol. 9, no. 1 (Summer):9-18.

"In recent months, concerns have been raised about the profitability prospects for hedge funds. This article argues that market participants' pessimistic view of the hedge fund industry's capacity to generate long-term returns is a direct result of their continued focus on alpha. It illustrates the importance of considering not only the exposure to the market (the traditional beta), but also other exposures (the alternative betas) to characterize alternative sources of hedge fund returns. It also revisits the capacity issue by distinguishing between market capacity and manager capacity. The results show that alternative betas are an important source of hedge fund returns that reduce the importance of alpha. The authors conclude that capacity issues do not significantly impact alpha by illustrating that alpha is generated by successful bets on numerous exposures rather than by exploiting market opportunities.” (p. 9) 
* Getmansky, Mila, Andrew W. Lo, and Igor Makarov. 2004. “An Econometric Model of Serial Correlation and Illiquidity in Hedge Fund Returns.” Journal of Financial Economics, vol. 74, no. 3 (December):529-609.

"The returns to hedge funds and other alternative investments are often highly serially correlated. In this paper, we explore several sources of such serial correlation and show that the most likely explanation is illiquidity exposure and smoothed returns. We propose an econometric model of return smoothing and develop estimators for the smoothing profile as well as a smoothing-adjusted Sharpe ratio. For a sample of 908 hedge funds drawn from the TASS database, we show that our estimated smoothing coefficients vary considerably across hedge-fund style categories and may be a useful proxy for quantifying illiquidity exposure." (p. 529)

* Gregoriou, Greg N., Georges Hübner, Nicolas Papageorgiou, and Fabrice Rouah. 2005. "Survival of Commodity Trading Advisors: 1990-2003." Journal of Futures Markets, vol. 25, no. 8 (August):795-815.

"This article investigates the mortality of Commodity Trading Advisors (CTAs) over the 1990-2003 period, a longer horizon than any encompassed in the literature. A detailed survival analysis over the full range of CTA classifications is provided, and it is found that the median lifetime of CTAs in this sample is different than previously documented. Through the implementation of nonparametric, parametric, and semiparametric statistical techniques, it is emphasized that CTA survivorship is heavily contingent on the strategy followed by the fund. Furthermore, a significant positive size effect on survival is shown, whereas poor returns, and to a lesser extent, high-risk exposure, appear to hasten mortality.” (p. 795)

* Hamza, Olfa, Maher Kooli, and Mathieu Roberge. 2006. "Further Evidence on Hedge Fund Return Predictability." Journal of Wealth Management, vol. 9, no. 3 (Winter):68-79.

"In this article, the authors provide new evidence of the out-of-sample predictability of hedge fund returns. They first adopt a rigorous model-construction process to find the best predictive variables for each hedge fund style. They then examine whether the perceived predictability could translate into profitable 'tactical style' allocation strategies. Nine out of ten hedge funds strategies outperform the passive benchmark. For robustness, they test the performance of optimized strategies and confirm the profitability of tactical style allocation based on the prediction of our multifactor models." (p. 68)

Henriksson, Roy D. 1984. "Market Timing and Mutual Fund Performance: An Empirical Investigation." Journal of Business, vol. 57, no. 1 (January):73-96.

"The evaluation of the performance of investment managers is a topic of considerable interest to practitioners and academics alike. Using both the parametric and non-parametric tests for the evaluation of forecasting ability presented by Henriksson and Merton, the market-timing ability of 116 open-end mutual funds is evaluated for the period 1968-80. The empirical results do not support the hypothesis that mutual fund managers are able to follow an investment strategy that successfully times the return on the market portfolio." (p. 73)

* Hsieh, David A. 2006. "The Search for Alpha-Sources of Future Hedge Fund Returns." CFA Institute Conference Proceedings Quarterly, vol. 23, no. 3 (September):79-89.

"Two types of hedge fund investors exist: alpha seekers and beta chasers. If alpha seekers dominate the market, the decline in alpha per dollar invested in the hedge fund industry is likely to continue as long as the supply of alpha is finite. If, however, beta chasers dominate, growth in the industry should be sustainable because beta return is easily replicated and, therefore, the supply of beta virtually unlimited.” (p. 79) 
* Jaeger, L., and C. Wagner. 2005. "Factor Modeling and Benchmarking of Hedge Funds: Can Passive Investments in Hedge Fund Strategies Deliver?” Journal of Alternative Investments, vol. 8, no. 3 (Winter):9-36.

"The hedge fund industry is starting to recognize that the main component of its returns corresponds to risk premia rather than market inefficiencies, i.e. from 'beta' instead of 'alpha.' This has some implication for the industry and investors, among which is the endeavor to construct investable benchmarks for hedge funds on the basis of an analysis of the underlying systematic risk factors. This issue is closely linked to the rationale for constructing investable versions of hedge fund indices. An important question is whether investable benchmarks based on risk factor analysis offer a valid, more theoretically sound, and cheaper alternative to the hedge fund index products currently available? This article reflects on this most recent discussion within the global hedge fund industry about the "beta versus alpha' controversy, investable hedge fund indices, and finally, capacity issues. It illustrates how the current research might turn the hedge fund industry upside down in coming years.” (p. 9)

* Kat, Harry M. 2003. "Taking the Sting Out of Hedge Funds.” Journal of Wealth Management, vol. 6, no. 3 (Winter):67-76.

"Although the inclusion of hedge funds in an investment portfolio can significantly improve that portfolio's mean-variance characteristics, it can also be expected to lead to significantly lower skewness and higher kurtosis. In this article, the author shows how this highly undesirable side effect can be neutralized by allocating a fraction of wealth to out-of-the-money put options on the relevant stock index. Roughly speaking, the costs of the proposed skewness reduction strategy will be higher (1) the higher the hedge fund allocation, (2) the lower the expected equity risk premium, and (3) the higher the bond allocation relative to the equity allocation. In the current low interest rate environment, for portfolios with a more or less equal allocation to stocks and bonds, the costs of skewness reduction are unlikely to be much higher than 1 percent per annum. For portfolios with relatively high bond allocations, however, the costs could amount to 3 percent or even more. This confirms that the benefits of hedge funds heavily depend on the portfolio they are added to and that the attractive mean-variance properties of (portfolios including) hedge funds may come at a significant price." (p. 67)

* — 2004. "Hedge Funds versus Common Sense: An Illustration of the Dangers of Mechanical Investment Decision Making." In Intelligent Hedge Fund Investing. Edited by Barry Schachter. London: Risk Books.

"It has become clear that hedge funds are a lot more complicated than common stocks and investment grade bonds and may not be as phenomenally attractive as many hedge fund managers and marketers want investors to believe. Hedge fund investing requires a more elaborate approach to investment decision making than most investors are used to. Mechanically applying the same decision-making processes that are typically used for stock and bond investment may lead to some very nasty surprises." (p. 9)

2005. "Integrating Hedge Funds into the Traditional Portfolio." Journal of Wealth Management, vol. 7, no. 4 (Spring):51-57.

"In this summary article, the author shows how investors can neutralize the unwanted skewness and kurtosis effects from investing in hedge funds by (1) purchasing out-of-the-money equity puts, (2) investing in managed futures, and/or by (3) overweighting equity market neutral and global macro and avoiding distressed securities and emerging market funds. The analysis suggests that all three alternatives are up to the job but also come with their own specific price tag." (p. 51) 
* _ 2007. "Alternative Routes to Hedge Fund Return Replication.” Journal of Wealth Management, vol. 10, no. 3 (Winter):25-39.

"The author starts with the observation that although institutions are still pouring more and more money into hedge funds, hedge fund performance is clearly deteriorating. In part, this reflects lower interest rates and a global decline in risk premiums. Part of hedge funds' disappointing performance, however, is also due to the huge inflow of institutional money itself. The author then notes that, driven by a desire to reduce costs and improve investor returns, the market has recently seen several attempts to 'replicate' hedge fund index returns. Stating that the driving force behind hedge fund replication is the realization that the majority of hedge fund managers do not have enough skill to make up for the fees they charge, the author argues that it may be worthwhile to replace the managers in question with a synthetic hedge fund. Synthetic hedge funds produce no pre-fee alpha, but they don't cost a fortune to run and may therefore very well produce significant after-fee alpha. In addition, synthetic hedge funds come with great improvements in liquidity, transparency, capacity, etc. The article proceeds to discuss three different approaches to replications." (p. 25)

* Kazemi, Hossein B., and Thomas Schneeweis. 2004. "Hedge Funds: Stale Prices Revisited.” Working paper, CISDM (April).

"The growth in hedge fund has in part been due to their historical return to risk performance. Concern, however, has been expressed that one reason for the superior return to risk tradeoff for hedge funds, is that, unlike traditional mutual funds, hedge funds often trade in illiquid securities and may have the ability to smooth prices such that reported volatility and systematic risk are less than actual volatility and systematic risk. In this paper we show that previous research which has used the lagged values of S\&P 500 returns to test the potential impact of stale prices may simply reflect a unique historical anomaly in the relationship between hedge fund returns and lagged returns on the S\&P 500. While price smoothing may still exist in various hedge fund strategies, we show that the empirical results presented in previous papers have an alternative explanation that is unrelated to stale prices or data smoothing." (p. 1)

* Kundro, Christopher, and Stuart Feffer. 2003. "Understanding and Mitigating Operational Risk in Hedge Fund Investments." Capco white paper series (March): www.capco.com/content/knowledge-ideas?q=content/research.

"As the hedge fund industry has grown explosively, so too has the list of fund failures and burned investors. To better understand the reason why hedge funds fail in ways that often result in substantial investor losses and how such failures could be prevented or at least avoided, Capco initiated a study. Our initial analysis shows that operational issues account for an alarmingly high proportion of hedge fund failures (50\%) and that expanding due diligence and monitoring practices to understand "back office' capabilities can make a big difference in preventing or avoiding these failures.” (p. 3)

*___ 2004. "Valuation Issues and Operational Risk in Hedge Funds." Working paper, Capco (March).

"In our recent study on the root causes of hedge fund failures, we identified a number of operational risk factors that together seem to account for approximately half of catastrophic cases. Issues related to valuation - the determination of fair-market value for all of the positions that make up a fund - underlie many of these operational risk factors. Recently, valuation problems have also been much in the news. These headlines suggest that the industry is not yet taking the steps needed to address problems in the valuation process. In fact, we believe that issues related to valuation of portfolios will likely become the next major 'black eye' for the hedge fund industry. Unless certain practices discussed in this paper become more widespread, we believe that hedge funds face a potential crisis of confidence with institutional and high net worth investors. Therefore, we are using this paper to consider the issues related to the valuation of hedge fund portfolios more closely, in particular as they pertain to the issue of managing operational risks associated with hedge fund investments." (p. 1) 
Liang, Bing. 1999. “On the Performance of Hedge Funds.” Financial Analysts Journal, vol. 55, no. 4 (July/ August):72-85.

"Empirical evidence indicates that hedge funds differ substantially from traditional investment vehicles, such as mutual funds. Unlike mutual funds, hedge funds follow dynamic trading strategies and have low systematic risk. Hedge funds' special fee structures apparently align managers' incentives with fund performance. Funds with 'high watermarks' (under which managers are required to make up previous losses before receiving any incentive fees) significantly outperform those without. Hedge funds provide higher Sharpe ratios than mutual funds, and their performance in the period of January 1992 through December 1996 reflects better manager skills, although hedge fund returns are more volatile. Average hedge fund returns are related positively to incentive fees, fund assets, and the lockup period." (p. 72)

- 2000. "Hedge Funds: The Living and the Dead." Journal of Financial and Quantitative Analysis, vol. 35, no. 3 (September):309-326.

"In this paper, we examine survivorship bias in hedge fund returns by comparing two large databases. We find that the survivorship bias exceeds 2 percent per year. We reconcile the conflicting results about survivorship bias in previous studies by showing that the two major hedge fund databases contain different amounts of dissolved funds. Empirical results show that poor performance is the main reason for a fund's disappearance. Furthermore, we find that there are significant differences in fund returns, inception date, net assets value, incentive fee, management fee, and investment styles for the 465 common funds covered by both databases. One database has more return and NAV observations, longer fund return history, and more funds with fee information than the other database. There are at least 5 percent return numbers and 5 percent NAV numbers which differ dramatically across the two databases. Mismatching between reported returns and the percentage changes in NAVs can partially explain the difference. The two databases also have different style classifications. Results of survivorship bias by styles indicate that the biases are different across styles and significant for ten out of fifteen styles in one database but none is significant for the other one." (p. 309)

Lo, Andrew W. 2001. "Risk Management for Hedge Funds: Introduction and Overview." Financial Analysts Journal, vol. 57, no. 6 (November/December):16-33.

"Although risk management has been a well-plowed field in financial modeling for more than two decades, traditional risk management tools such as mean-variance analysis, beta, and value-at-risk do not capture many of the risk exposures of hedge-fund investments. In this article, I review several unique aspects of risk management for hedge funds-survivorship bias, dynamic risk analytics, liquidity, and nonlinearities - and provide examples that illustrate their potential importance to hedgefund managers and investors. I propose a research agenda for developing a new set of risk analytics specifically designed for hedge-fund investments, with the ultimate goal of creating risk transparency without compromising the proprietary nature of hedge-fund investment strategies.” (p. 16)

—. 2002. “The Statistics of Sharpe Ratios." Financial Analysts Journal, vol. 58, no. 4 (July/August):36-52.

"The building blocks of the Sharpe ratio-expected returns and volatilities-are unknown quantities that must be estimated statistically and are, therefore, subject to estimation error. This raises the natural question: How accurately are Sharpe ratios measured? To address this question, I derive explicit expressions for the statistical distribution of the Sharpe ratio using standard asymptotic theory under several sets of assumptions for the return-generating process-independently and identically distributed returns, stationary returns, and with time aggregation. I show that monthly Sharpe ratios cannot be annualized by multiplying by $\sqrt{12}$ except under very special circumstances, and I derive the correct method of conversion in the general case of stationary returns. In an illustrative empirical example of mutual funds and hedge funds, I find that the annual Sharpe ratio for a hedge fund can 
be overstated by as much as 65 percent because of the presence of serial correlation in monthly returns, and once this serial correlation is properly taken into account, the rankings of hedge funds based on Sharpe ratios can change dramatically." (p. 36)

Lowenstein, Roger. 2000. When Genius Failed: The Rise and Fall of Long-Term Capital Management. New York: Random House.

This book tells the compelling story of Long-Term Capital Management. In 1993, the best and brightest bond arbitrageurs allied themselves with two future Nobel Prize winners to form a firm that was so sure of its models, it believed it could use leverage without limit to generate fabulous profits. But by 1997, when the Russia default touched off a scenario not anticipated by the models, the staggering amounts of leverage used by LTCM threatened to bring down the world's financial system.

* Malkiel, Burton G., and Atanu Saha. 2005. "Hedge Funds: Risk and Return.” Financial Analysts Journal, vol. 61, no. 6 (November/December):80-88.

"From a database that is relatively free of bias, this article provides measures of the returns of hedge funds and of the distinctly non-normal characteristics of the data. The results include risk-adjusted measures of performance and tests of the degree to which hedge funds live up to their claim of market neutrality. The substantial attrition of hedge funds is examined, the determinants of hedge fund demise are analyzed, and results of tests of return persistence are presented. The conclusion is that hedge funds are riskier and provide lower returns than is commonly supposed.” (p. 80)

* Naik, Narayan Y., and Vikas Agarwal. 2000. "On Taking the 'Alternative' Route: The Risks, Rewards, and Performance Persistence of Hedge Funds.” Journal of Alternative Investments, vol. 2, no. 4 (Spring):6-23.

"The risk-return characteristics, risk exposures, and performance persistence of various hedge fund strategies remains an area of interest to alternative asset investors. Using a database on hedge fund indices and individual hedge fund managers in a mean-variance framework, results show that a combination of alternative investments and passive indexing provides a significantly better risk-return trade-off than passively investing in the different asset classes. Moreover, using parametric and nonparametric methods, a reasonable degree of persistence is found for hedge fund managers. This seems to be attributable more to the losers continuing to be losers instead of winners continuing to be winners and highlights the importance of manager selection in case of hedge funds." (p. 6)

* Sharma, Milind. 2004. “A.I.R.A.P-Alternative Views on Alternative Investments.” Working paper (January).

"This paper investigates issues of risk-adjusted performance, value added and leverage for hedge funds. It applies AIRAP (Alternative Investments Risk Adjusted Performance), which is the power utility implied certain return that a risk-averse investor would trade off for holding risky assets, to hedge fund indices and individual hedge fund data. Inferences are made about the value added by hedge funds and the difference between directional and non-directional strategies. Evidence of nonnormality, higher moment risks, and the trade-off between mean-variance profile vis-a-vis skewness and kurtosis is noted across style categories. Further, survivorship bias is estimated across style categories in the first four moments." (p. 1)

* Stulz, René. 2007. "Hedge Funds: Past, Present, and Future." Journal of Economic Perspectives, vol. 21, no. 2 (Spring):175-194.

"Assets managed by hedge funds have grown faster over the last 10 years than assets managed by mutual funds. Hedge funds and mutual funds perform the same economic function, but hedge funds are largely unregulated while mutual funds are tightly regulated. This paper compares the organization, performance, and risks of hedge funds and mutual funds. It then examines whether one can expect increasing convergence between these two investment vehicles and concludes that the performance gap between hedge funds and mutual funds will narrow, that regulatory developments will limit the flexibility of hedge funds, and that hedge funds will become more institutionalized." (p. 175) 
* Till, Hilary. 2004. "Benefits and Costs of Illiquidity." In Intelligent Hedge Fund Investing. Edited by Barry Schachter. London: Risk Books.

"Illiquidity affects the valuation of hedge fund investments in several ways. Despite the quantitative definition of illiquidity, some of those effects are behavioral. Further, and somewhat surprising, not all the effects might be considered as negative. We discuss what we know about the various impacts of illiquidity on the decision to invest in hedge funds, and, where appropriate, how an investor may take aspects of illiquidity into account to compare investments with dissimilar liquidity." (p. 75)

*Weisman, Andrew. 2002. "Informationless Investing and Hedge Fund Performance Measurement Bias." Journal of Portfolio Management, vol. 28, no. 4 (Summer):80-91.

"Asset managers have the ability to engage in essentially informationless' investment strategies that can produce the appearance of return enhancement without necessarily providing any value to an investor. Statistical estimates of risk, return, and association therefore frequently mischaracterize investment returns. These mischaracterizations, the author argues, have significant negative implications for both the asset allocation process and the validity of related academic research. $\mathrm{He}$ presents three specific informationless investment strategies, which he believes are endemic to the hedge fund industry, and assesses their consequences with respect to performance measurement and asset allocation." (p. 80)

This article qualifies for 0.5 CE credits. 